\title{
ANALISIS RISIKO BENCANA GEMPA DI KABUPATEN SERANG
}

\section{EARTHQUAKE HAZARD RISK ANALYSIS IN SERANG DISTRICT}

\author{
Heru Sri Naryanto \\ Pusat Teknologi Reduksi Risiko Bencana (PTRRB), \\ Kedeputian TPSA - Badan Pengkajian dan Penerapan Teknologi (BPPT) \\ Gedung Geostech, Lantai 1, Kompleks Puspiptek Serpong, Tangerang Selatan \\ email: heru.naryanto@bppt.go.id
}

\begin{abstract}
Serang District is part of the Sunda Strait area, located between two world plates, namely the Indo-Australian Plate and the Eurasian Plate which produces one of the highest tectonic and seismic activities. Peak ground acceleration map data is especially important to use in earthquake hazard analysis. Vulnerability maps are made based on social vulnerability, namely: population density, gender ratio, poverty ratio, difable ratio, and age group ratio. $A$ disaster risk map is a thematic map that contains information on the magnitude of losses, namely loss of life, damage to property, and disruption to economic loss due to a disaster. The basic concept of disaster risk is a function of the hazards that occur in an area that has a susceptible condition. The villages that have the widest high-risk areas for earthquakes in Cinangka District are Bantarwaru Village, Kubang Baros Village, Cikolelet Village, Umbul Tanjung Village, while Padarincang District is Cibojong Village. Most of the villages with high risk of earthquakes are in the southwest part which is also included in the high-level earthquake hazard zone map. Information on the risk of earthquake disasters in Serang District can be used as a reference in preparing action plans for earthquake risk reduction at every stage of the condition (prevention, adaptation, mitigation, and preparedness), as well as a more effective and integrated development planning process in reducing the impact of casualties both life and property that may occur.
\end{abstract}

Keywords: erthquake, risk, Serang, disaster risk reduction

\begin{abstract}
ABSTRAK
Kabupaten Serang merupakan bagian dari kawasan Selat Sunda, terletak di antara dua lempeng dunia yaitu Lempeng Indo-Australia dan Lempeng Eurasia yang menghasilkan salah satu aktivitas tektonik dan kegempaan yang sangat tinggi. Data peta percepatan puncak tanah sangat penting digunakan dalam analisis bahaya gempabumi. Peta kerentanan dibuat berdasarkan kerentanan sosial, yaitu: kepadatan penduduk, rasio jenis kelamin, rasio kemiskinan, rasio disabilitas dan rasio kelompok umur. Peta risiko bencana merupakan peta tematik yang berisi informasi terhadap besar kerugian, yaitu kehilangan nyawa, kerusakan harta benda, dan gangguan pada kegiatan ekonomi akibat suatu bencana. Konsep dasar risiko bencana merupakan fungsi dari bahaya yang terjadi pada suatu daerah yang memiliki kondisi rentan. Desa-desa yang mempunyai wilayah berisiko tinggi gempabumi terluas di Kecamatan Cinangka terdapat di Desa Bantarwaru, Desa Kubang Baros, Desa Cikolelet, Desa Umbul Tanjung, sedangkan di Kecamatan Padarincang terdapat di Desa Cibojong. Sebagian besar dari desa-desa yang berisiko tinggi terhadap gempabumi ada di bagian barat daya yang juga termasuk ke dalam peta zona bahaya tingkat tinggi gempabumi. Informasi risiko bencana gempabumi di Kabupaten Serang bisa dijadikan acuan dalam menyusun rencana tindak pengurangan risiko bencana gempabumi dalam setiap tahapan kondisi (pencegahan, adaptasi, mitigasi, dan kesiapsiagaan), serta proses perencanaan pembangunan yang lebih efektif dan terintegrasi dalam mengurangi dampak korban baik jiwa maupun harta yang mungkin terjadi.
\end{abstract}

Kata kunci: gempa, risiko, Serang, pengurangan risiko bencana 


\section{PENDAHULUAN}

\subsection{Latar Belakang Permasalahan}

Kabupaten Serang terletak di bagian barat laut Provinsi Banten, secara administratif dibagi menjadi 29 kecamatan dan 326 desa. Luas wilayah Kabupaten Serang adalah 1.467,35 km², berada pada ketinggian 0 sampai $1.778 \mathrm{~m} \mathrm{dpl}$, dan pada umumnya didominasi oleh morfologi yang relatif datar hingga sedikit bergelombang (BPS Kab. Serang, 2018; Pemerintah Kab. Serang, 2019).

Kabupaten Serang terletak di kawasan Selat Sunda. Selat Sunda merupakan bagian dari kepulauan Indonesia yang memiliki kondisi geologi yang unik, terletak di antara dua lempengan besar yaitu Lempeng Indo-Australia di selatan dan Lempeng Eurasia di utara. Penunjaman antara kedua lempeng tersebut menghasilkan salah satu aktivitas kegempaan paling aktif di dunia (Candra et al., 2017). Kondisi tektonik di kawasan Selat Sunda sangat aktif dan banyak kejadian gempa yang bersumber di kawasan tersebut. Lempeng Indo-Australia yang bertumbukan dan menunjam masuk ke dalam Lempeng Eurasia membentuk zona penunjaman antar lempeng (subduksi) dan patahan-patahan aktif. Keberadaan zona subduksi serta patahan aktif yang terbentuk terjadi kawasan Selat Sunda, bisa berfungsi sebagai sumber gempa yang menyebabkan banyak gempa terjadi di kawasan tersebut (Handayani \& Harjono, 2008; Naryanto, 2008).

Hampir setiap saat gempa terjadi di Indonesia bagian barat, baik yang dirasakan manusia maupun yang tercatat oleh instrumen pencatat gempa. Gempa yang dianggap merusak sering terjadi dengan besaran lebih dari 5 Skala Richter (SR). Sampai pada dekade awal abad 21, di Indonesia bagian barat telah banyak sekali terjadi gempa merusak yang sebagian diantaranya bahkan diikuti oleh gelombang tsunami yang dahsyat (Naryanto, 2003; Naryanto, 2008).

Menurut Rusmana dkk. (1991), bagian selatan Kabupaten Serang terdiri atas batuan sedimen, batuan gunungapi, batuan terobosan dan endapan aluvium yang berumur mulai Miosen awal hingga Resen, dengan satuan tertua daerah ini adalah Formasi Bayah yang berumur Eosen. Formasi Bayah terdiri dari tiga anggota yaitu anggota konglomerat, batulempung, dan batugamping. Selanjutnya adalah Formasi Cicarureup, Formasi Cijengkol, Formasi Citarate, Formasi Cimapang, Formasi
Sareweh, Formasi Badui, Formasi Cimanceuri, dan Formasi Cikotok. Secara umum diketahui, bahwa sebagian besar wilayah ini terdiri dari batuan volkanik dengan endapan permukaan yang sebagian besar berada di pantai utara dan bagian timur Kabupaten Serang.

Gempa merupakan bencana alam yang masih sangat sulit dan kompleks untuk diprediksi sampai sekarang ini, kapan tepatnya bencana tersebut akan terjadi. Berkaca dari pengalaman kejadian gempa-gempa besar yang melanda di Indonesia akhir-akhir ini, memberi pembelajaran bahwa upaya mitigasi, adaptasi, dan kesiapsiagaan harus dilakukan lebih baik lagi sehingga dampak dari korban baik jiwa maupun harta bisa diminimalkan (Naryanto, 2008).

Risiko bencana gempa sangat ditentukan oleh kepadatan penduduk dan infrastruktur yang telah dibangun pada suatu wilayah yang telah dinyatakan rawan terhadap bahaya gempa (Soehaimi, 2008). Kabupaten Serang termasuk salah satu wilayah yang mempunyai infrastruktur dan penduduk padat yang berada pada zona potensi bahaya gempa.

Menurut UU No 24 Tahun 2007, diharapkan penanggulangan bencana dapat dilakukan dengan lebih terarah, menyeluruh, efisien, terpadu, serta terkoordinasi dengan baik dengan dibentuknya BNPB di tingkat pusat dan BPBD di daerah. Dengan mengoptimalkan peran BPBD, maka sangat dibutuhkan data kajian terhadap aspek kebencanaan dalam setiap rencana pembangunan mulai dari yang bersifat makro-politis sampai dengan yang bersifat mikro-teknis (Naryanto, 2017; Naryanto, 2019a, 2019b). Dalam tulisan ini dikaji risiko bencana gempabumi di Kabupaten Serang, sebagai data dan informasi yang diharapkan menjadi acuan dalam proses perencanaan pembangunan serta kegiatan pengurangan risiko bencana yang lebih efektif dan terintegrasi untuk mengurangi dampak korban jiwa maupun harta yang mungkin terjadi.

\section{BAHAN DAN METODE}

\subsection{Lokasi dan Waktu Penelitian}

Penelitian kegiatan dilakukan di Kabupaten Serang, Provinsi Banten. Penelitian dilakukan selama 8 bulan, dari bulan Maret sampai November 2017. 


\subsection{Metode Pengumpulan Data}

Metode pengumpulan data di Kabupaten Serang dilaksanakan sebagai berikut:

a. Koordinasi dengan instansi terkait,

b. Pengumpulan data sekunder dan referensi terkait,

c. Pengumpulan data primer langsung di lapangan,

d. Pengolahan dan analisis data secara spasial, kualitatif, dan kuantitatif,

e. Validasi data,

f. Penyusunan dokumen peta bahaya, kerentanan, dan risiko gempabumi,

g. Evaluasi data,

h. Penyelesaian data,

i. Penyusunan rencana tindak.

\subsection{Metode Analisis Data}

Metodologi yang digunakan analisis risiko bencana gempabumi di Kabupaten Serang dilakukan melalui analisis teknis dengan menggunakan bantuan perangkat lunak extension spatial analyst pada software ArcGIS 10.6. Analisis peta dengan melakukan pengolahan data kontur rupabumi BIG Skala 1: 25.000 melalui software Global Mapper.

\subsection{Metode Pembuatan Peta Bahaya, Kerentanan, dan Risiko Bencana Gempabumi}

Sebagai dasar utama dalam menentukan zonasi bahaya, kerentanan, dan risiko bencana gempabumi secara umum adalah dengan menggunakan Peraturan Kepala BNPB No. 02 Tahun 2012 tentang Pedoman Umum Pengkajian Risiko Bencana (BNPB, 2012) dan peta risiko bencana (BNPB, 2016). Metodologi mengenai potensi bahaya gempabumi di Kabupaten Serang dituangkan ke dalam peta potensi bahaya gempabumi, dengan dasar utama menggunakan data peta puncak percepatan tanah (peak ground acceleration/PGA) yang dikeluarkan oleh Kementerian PU (2017). Pertimbangan berbagai parameter lain dalam menentukan zonasi gempabumi tersebut adalah sebagai berikut:

a. DEM SRTM 90 meter,

b. Data seismisitas NEIC USGS (kekuatan atau energi, jarak episentrum, interval, kondisi bawah tanah),

c. Peta geologi dari Badan Geologi skala $1: 250.000$,

d. Data kegempaan dari BMKG,

e. Zona lempeng tektonik,

f. Sejarah kegempaan,

g. Kondisi patahan-patahan sekunder yang terdapat di Kabupaten Serang,

h. Survei lapangan,

i. Analisis data.

Kerentanan adalah suatu kondisi dari suatu komunitas atau masyarakat yang mengarah atau menyebabkan ketidakmampuan dalam menghadapi ancaman bencana. Kerentanan objek yang terancam bencana dihitung berdasarkan kerentanan sosial. Kerentanan sosial terbentuk dari parameter kepadatan penduduk dan kelompok rentan. Kelompok rentan meliputi: rasio jenis kelamin, rasio kelompok umur rentan, rasio penduduk miskin, serta rasio penduduk cacat (BNPB, 2016) (Tabel 1). Analisis secara spasial, masing-masing nilai parameter didistribusikan dalam wilayah permukiman per desa dalam bentuk grid raster (piksel) berdasarkan data kependudukan yang ada.

Tabel 1. Tabel Skoring Kerentanan Sosial (BNPB, 2016).

\begin{tabular}{|c|c|c|c|c|}
\hline \multirow{2}{*}{ Parameter } & \multirow{2}{*}{ Bobot } & \multicolumn{3}{|c|}{ Kelas } \\
\hline & & Rendah & Sedang & Tinggi \\
\hline Kepadatan Penduduk & 60 & $<5$ jiwa/ha & $\begin{array}{l}5-10 \\
\text { jiwa/ha }\end{array}$ & $\begin{array}{c}>10 \\
\text { jiwa/ha }\end{array}$ \\
\hline \multicolumn{5}{|l|}{ Kelompok Rentan } \\
\hline Rasio Jenis Kelamin (10\%) & \multirow{4}{*}{40} & $>40$ & $20-40$ & $<20$ \\
\hline Rasio Kelompok Umur Rentan (10\%) & & \multirow{3}{*}{$<20$} & \multirow{3}{*}{$20-40$} & \multirow{3}{*}{$>40$} \\
\hline Rasio Penduduk Miskin (10\%) & & & & \\
\hline Rasio Penduduk Cacat (10\%) & & & & \\
\hline
\end{tabular}


Peta risiko bencana adalah peta tematik yang berisi informasi mengenai besar kerugian (kerusakan harta benda, kehilangan nyawa, serta gangguan terhadap kegiatan ekonomi yang diderita akibat suatu bencana). Potensi bahaya yang ada pada suatu daerah tidak harus menimbulkan risiko bencana. Konsep dari risiko bencana adalah fungsi dari bahaya (hazard) yang terjadi pada suatu daerah yang mempunyai kondisi rentan (vulnerable). Kerentanan adalah kondisi ketidakmampuan dalam menghadapi bahaya seperti keadaan sosial masyarakat, kerapuhan ekonomi, infrastruktur, dan keadaan lingkungan. Sedangkan kapasitas merupakan kekuatan atau sumberdaya dalam menghadapi bencana (budaya sadar bencana, kesiapan masyarakat, dan kebijakan) (BNPB, 2012; BNPB, 2016).

Fungsi dari risiko bencana dapat digambarkan sebagai berikut:

Risiko $=\underline{\text { Bahaya } \mathrm{x} \text { Kerentanan }}$

Kapasitas

\section{HASIL DAN PEMBAHASAN}

\subsection{Analisis Kegempaan di Kabupaten Serang dan Sekitarnya}

Gempa sering terjadi di wilayah Kabupaten Serang, disebabkan karena wilayah tersebut terletak pada zona batas dua lempeng besar, yaitu Lempeng Eurasia dan Lempeng Indo-Australia. Pergerakan tektonik antarlempeng bumi ini menyebabkan deformasi pada batas lempeng, pembentukan patahan-patahan aktif baik di wilayah daratan maupun di dasar lautan. Batas lempeng dan patahan-patahan aktif ini menjadi sumber dari gempa-gempa tektonik yang dapat menimbulkan bencana terhadap masyarakat di kawasan tersebut (Naryanto, 2008; Candra et al., 2017).

Pendapat tersebut telah diperkuat oleh Harjono et al. (1991), yang memberikan buktibukti bahwa dua dari tiga zona kegempaan dikerak bagian atas mengelompok di bawah kompleks Krakatau dan Graben Semangko. Zona tersebut bersifat tektonik dan dapat dihubungkan dengan tarikan di dalam Selat Sunda. Hasil analisis stress tensor oleh Wilson et al. (1998), menunjukkan tarikan ke arah $\mathrm{N} 130^{\circ} \mathrm{E}$, searah dengan zona Sesar Sumatra. Sementara Lempeng Indo-Australia di sekitar Palung Sunda bergerak kurang lebih ke arah utara $\left(\mathrm{N} 3^{\circ} \mathrm{E}\right)$ dengan kecepatan relatif berkisar 6-7 cm/tahun. Bentuk geometri Sumatra dan Jawa, menunjukkan penunjaman berarah normal terhadap Pulau Jawa dan berarah miring terhadap Pulau Sumatra.

Gempa di zona subduksi terjadi oleh tegasan yang terakumulasi akibat kontak gesekan antara kedua lempeng tektonik. Pada patahan slip selama terjadinya gempa, tegasan yang terakumulasi pada batas lempeng di dalam zona rupture akan terlepaskan seluruhnya atau sebagian (Yudicara dan Budiono, 2008). Gempa yang berasal dari kegiatan penunjaman terkonsentrasi di wilayah sebelah barat daya Selat Sunda dengan kekuatan mulai dari yang bersifat mikro hingga makro ( $<3 \mathrm{Mw}$ sampai $>6 \mathrm{Mw}$ ), kedalaman yang bervariasi: dangkal $(<50 \mathrm{~km})$, hingga menengah $(120 \mathrm{~km})$, dan dalam $(>120 \mathrm{~km})$. Sementara itu, untuk gempa tektonik yang berasal dari patahan aktif biasanya mempunyai kedalaman dangkal $(<30 \mathrm{~km})$ dan berkekuatan <6 SR (Soehaimi et al., 2019).

Data sejarah kegempaan dianalisis dari situs USGS (United States Geological Survey) bagian National Earthquake Information Center (NEIC) (USGS, 2017). Hasil analisis tersebut dapat memberikan informasi berupa sejarah gempa dalam radius yang diinginkan untuk satu lokasi. Dengan memasukkan data sekitar Kabupaten Serang yang berupa gempa dengan kekuatan 4 sampai 7 SR selama 20 tahun terakhir dari tahun 1997-2017, hasilnya bisa dilihat pada Gambar 1.

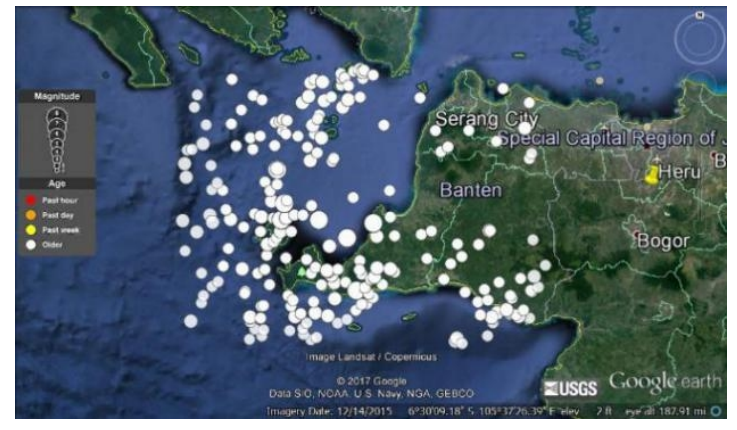

Gambar 1. Gempa dengan Kekuatan 4-7 SR di Sekitar Kabupaten Serang Selama 20 Tahun Terakhir dari Tahun 1997-2017 (Sumber: NEIC Earthquake Search Results, USGS Earthquake Data Base)

Berdasarkan peta percepatan puncak di batuan dasar SB untuk probabilitas $10 \%$ terlampaui dalam 50 tahun yang dikeluarkan oleh Kementerian PU (2017), Kabupaten Serang sebagian besar mempunyai harga PGA 
antara 0,2-0,4 g dan sebagian kecil di daerah selatan termasuk dalam skala $0,4-0,5 \mathrm{~g}$. Menurut klasifikasi dari USGS, skala 0,2-0,4 g termasuk moderate (sedang) sampai sedangtinggi setara dengan skala MMI VII-VIII, sedangkan skala 0,4-0,5 g termasuk klasifikasi sedang-tinggi (skala MMI VIII) (Gambar 2 dan $3)$.

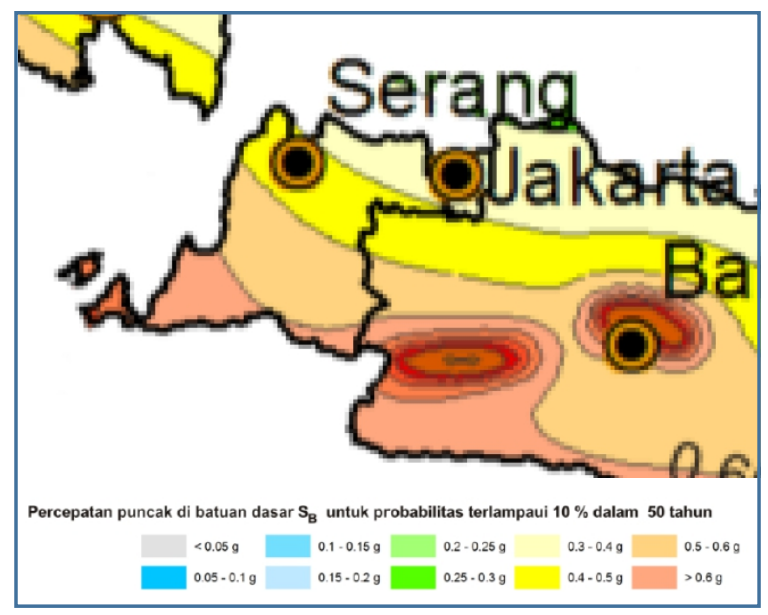

Gambar 2. Kabupaten Serang Sebagian Besar Mempunyai Harga PGA antara 0,2-0,4 g

Berdasarkan Peta Percepatan Puncak yang

Dikeluarkan oleh Kementerian PU (2017)

Berdasarkan klasifikasi besar getaran gempabumi dari Skala Intensitas Mercalli Modifikasi (Modified Mercalli Intensity/MMI) dan USGS, maka tingkat bahaya goncangan gempabumi dapat dilakukan klasifikasi. Pada skala Intensitas Mercalli Modifikasi, terlihat bahwa skala VI MMI merupakan batas permulaan dari adanya kerusakan (kecil). Disebutkan bahwa goncangan dalam skala VI MMI dapat dirasakan oleh semua orang, sebagian besar ketakutan dan lari keluar, susah berdiri tegap, jendela dan beberapa perkakas gelas pecah, rak buku dan perkakas lain terguling dan sedikit plester tembok mulai terkelupas. Klasifikasi VI MMI ini ekuivalen dengan besar percepatan tanah puncak di permukaan sebesar 9,2-18\%g $(0,092-0,18 \mathrm{~g})$ dan diklasifikasikan oleh USGS ke dalam tingkat kerusakan ringan.

Pada besaran skala VII MMI menurut klasifikasi skala Intensitas Mercalli Modifikasi, gambaran kerusakan yang mungkin terjadi adalah bangunan sulit berdiri, furniture rusak, kerusakan sedikit pada bangunan dengan desain dan konstruksi yang baik, terjadi kerusakan ringan sampai sedang untuk ratarata bangunan yang dibangun secara baik, terjadi kerusakan yang cukup berarti pada bangunan yang didirikan dengan desain buruk, beberapa cerobong rusak, dirasakan oleh orang yang sedang mengendarai motor. Sedangkan skala sedang sampai tinggi mempunyai besaran MMI sekitar skala VIII. Pada besaran skala VIII MMI, gambaran kerusakan yang mungkin terjadi adalah terjadinya sedikit kerusakan pada struktur yang didesain khusus. Beberapa bagian dari bangunan (dengan kualitas rata-rata) roboh. Kerusakan hebat pada bangunan berstruktur buruk, sementara cerobong, tumpukan barang, monumen, dinding roboh.

Besaran tingkatan kegempaan tergantung jarak terhadap sumber gempa dan kondisi batuan setempat. Batuan yang kuat mempunyai daya tahan terhadap goncangan gempabumi yang mengenai wilayah tersebut. Sumber gempa yang bisa menyebabkan goncangan di Kabupaten Serang berasal dari gesekan pada zona subduksi di Kawasan Selat Sunda, selatan Jawa maupun barat Sumatra. Patahan-patahan aktif juga banyak terjadi di sekitar Kabupaten Serang. Banyaknya patahan-patahan aktif yang berada di zona subduksi tersebut serta patahan aktif yang terdapat di sekitar akan bisa memicu terjadinya goncangan dan kerusakan yang lebih tinggi.

Selain gempabumi, Kabupaten Serang juga berpotensi terhadap tsunami, yaitu Kecamatan Anyar dan Kecamatan Cinangka yang berhadapan langsung dengan Selat Sunda. Sementara di wilayah pantai utara meliputi kecamatan-kecamatan: Pulo Ampel, Bojonegara, Kramatwatu, Pontang, Tirtayasa, dan Tanara (Naryanto, 2019).

\subsection{Peta Bahaya Gempabumi}

Dari hasil analisis bahaya gempabumi yang telah dilakukan, diketahui bahwa zona bahaya gempabumi tinggi di Kabupaten Serang terdapat di bagian barat daya, yaitu di sebagian kecamatan-kecamatan Cinangka, Padarincang, Ciomas, Mancak dan Anyar. Sedangkan zona bahaya gempabumi sedang terdapat hampir menyeluruh pada kecamatan di Kabupaten Serang. Daerah zona bahaya gempabumi tinggi mempunyai luas 20.408 ha, dan daerah bahaya sedang mempunyai luas 125.787 ha. Bila dilihat pada tingkatan kecamatan, diketahui bahwa dari 29 kecamatan yang ada di Kabupaten Serang, ternyata hanya ada 5 kecamatan yang mempunyai area berbahaya tinggi. Adapun ke 5 kecamatan tersebut, dimulai dari luasan 
terbesar adalah Kecamatan Cinangka dengan area berzona bahaya tinggi seluas 11.221 ha, Padarincang 6.046 ha, Kecamatan Ciomas 2.812 ha, Kecamatan Mancak 324 ha, dan
Kecamatan Anyar seluas 845 ha (Gambar 4) (BPPT-BPBD Kab. Serang, 2017; Naryanto \& Zahro, 2017).

\begin{tabular}{|c|c|c|c|c|c|c|c|c|c|}
\hline $\begin{array}{c}\text { PERCEIVED } \\
\text { SHAKING }\end{array}$ & Not felt & Weak & Light & Moderate & Strong & Xéry strong & Severe & Violent & Extreme \\
\hline $\begin{array}{c}\text { POTENTIAL } \\
\text { DAMAGE }\end{array}$ & none & none & none & Very light & Light & Moderate & Mod./Heavy & Heavy & Very Heavy \\
\hline PEAK ACC.(\%g) & $<0.05$ & 0.3 & 2.8 & 6.2 & 12 & 22 & 40 & 75 & $>139$ \\
\hline PEAK VEL.(cm/s) & $<0.02$ & $\mathbf{0 . 1}$ & $\mathbf{1 . 4}$ & $\mathbf{4 . 7}$ & $\mathbf{9 . 6}$ & $\mathbf{2 0}$ & $\mathbf{4 1}$ & $\mathbf{8 6}$ & $>\mathbf{1 7 8}$ \\
\hline $\begin{array}{c}\text { INSTRUMENTAL } \\
\text { INTENSITY }\end{array}$ & $\mathrm{I}$ & II-III & IV & $\mathbf{V}$ & VI & VII & VIII & IX & X+ \\
\hline
\end{tabular}

Gambar 3. Skala Besaran PGA (g) Kesetaraannya dengan Besaran Intensitas (MMI), Kabupaten Serang Termasuk Skala VII-VIII (Sumber: USGS, 2017)

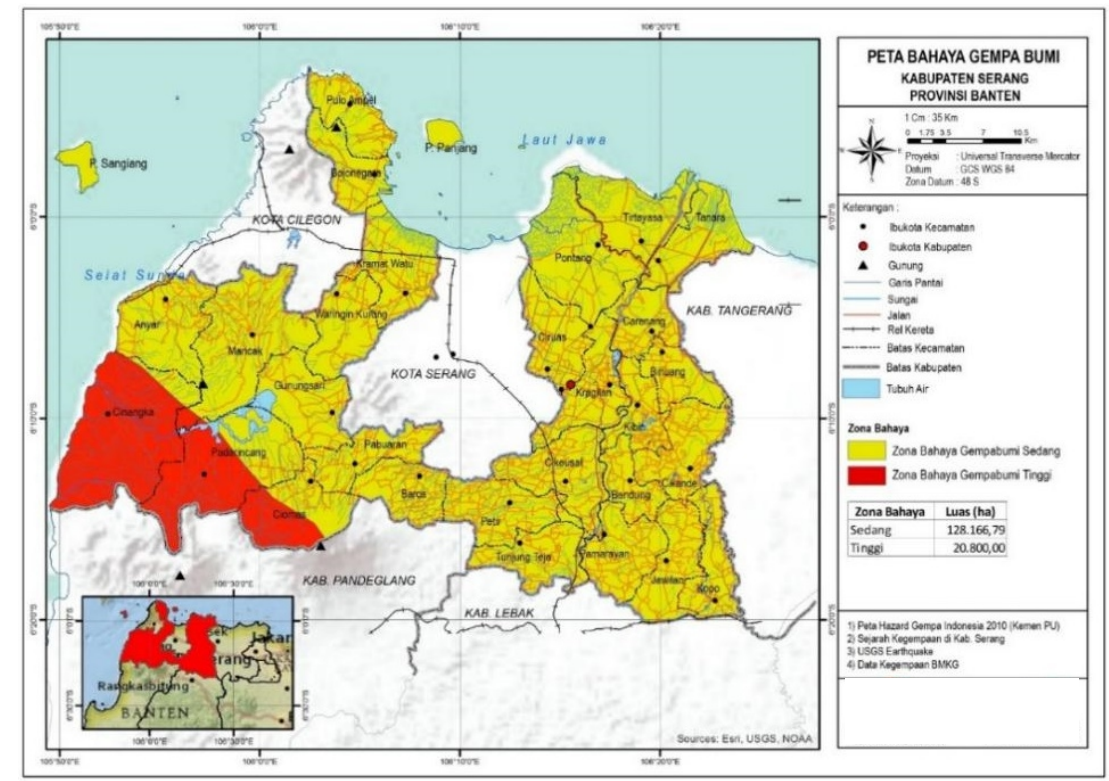

Gambar 4. Peta Bahaya Gempabumi Kabupaten Serang (Sumber: Hasil Pengolahan Data, 2017)

\subsection{Peta Kerentanan}

Pembuatan peta kerentanan dalam kegiatan ini digunakan kerentanan sosial. Indikator yang digunakan untuk kerentanan sosial adalah kepadatan penduduk, rasio jenis kelamin, rasio kemiskinan, rasio orang cacat dan rasio kelompok umur. Sumber informasi yang digunakan untuk analisis kerentanan terutama berasal dari data terkini Dinas Kependudukan dan Pencatatan Sipil Kabupaten Serang Dalam Angka (BPS Kabupaten Serang, 2018)

Peta kerentanan Kabupaten Serang dibuat dari peta-peta kerentanan kepadatan penduduk, rasio jenis kelamin, rasio penduduk miskin, dan rasio usia ketergantungan. Peta kerentanan merupakan gabungan dari 4 peta tersebut dengan bobot kepadatan penduduk (60\%), dan kelompok rentan (rasio jenis kelamin, rasio penduduk miskin, dan rasio usia ketergantungan) (40\%). Peta kerentanan total didapatkan dari hasil overlay keempat peta tersebut yang ditunjukkan pada Gambar 5.

\subsection{Peta dan Analisis Risiko Gempabumi di Kabupaten Serang}

Untuk mengurangi dampak gempabumi ini, dapat dilakukan dengan melakukan kajian risiko terhadap daerah yang rawan gempabumi. Melalui kajian risiko ini akan diketahui daerah mana saja yang mempunyai tingkat risiko tinggi, yang nantinya bisa dilakukan prioritas-prioritas penanganannya. Dari kajian risiko ini pula akan 
diketahui faktor apa saja yang menyebabkan tingginya risiko yang ada. Selanjutnya dengan mengetahui faktor utama penyumbang tingginya risiko yang muncul, akan dapat dilakukan tindakan penurunan risiko yang ada.

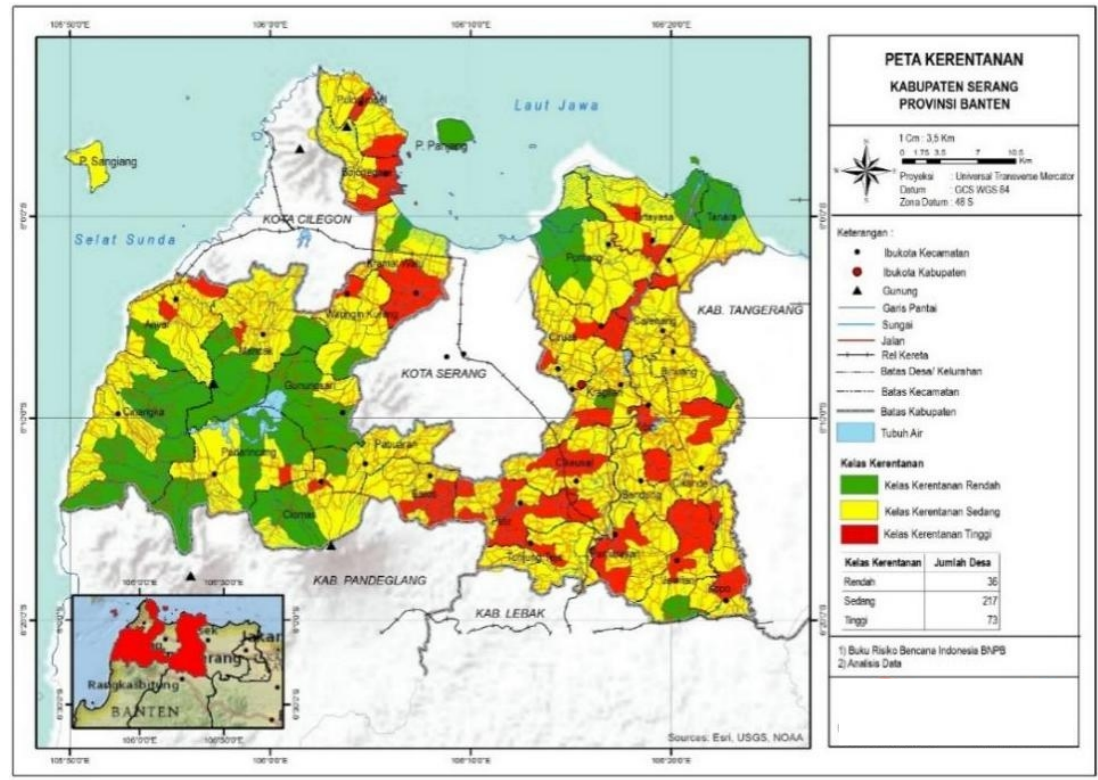

Gambar 5. Peta Kerentanan Kabupaten Serang (Sumber: Hasil Pengolahan Data, 2017)

Masalah risiko bencana, biasanya melibatkan tiga faktor utama, yaitu bahaya, kerentanan dan kapasitas. Analisis risiko bencana gempabumi di Kabupaten Serang ini tidak memasukkan parameter kapasitas daerah. Analisis risiko yang dilakukan di sini hanya akan mempertimbangkan faktor bahaya dan faktor kerentanan terutama kerentanan sosial yang meliputi jumlah penduduk, rasio umur rentan, rasio kemiskinan dan lain sebagainya.

Analisis risiko bencana gempabumi melibatkan parameter bahaya dan kerentanan. Dengan memakai prinsip perhitungan, ditetapkan nilai risiko yang dihasilkan diklasifikasikan menjadi 3 kelas, yaitu tingkat risiko rendah, sedang, dan tinggi dan dituangkan dalam bentuk peta risiko bencana gempabumi (Gambar 6). Kabupaten Serang dengan 29 kecamatan mempunyai luas wilayah 145.623 ha. Persebaran daerah berisiko tinggi hanya terdapat di bagian barat daya dari wilayah Kabupaten Serang. Hal ini hampir berhimpit dengan sebaran zona bahaya tingkat tinggi. Daerah berisiko sedang dan rendah, hampir tersebar di seluruh wilayah Kabupaten Serang secara sporadis merata. Melihat sebaran ini, menunjukkan bahwa tingginya risiko yang ada di sisi bagian barat daya adalah akibat kontribusi besar dari faktor tingkat bahayanya, sedangkan untuk tingkat risiko sedang yang tersebar di bagian lain adalah akibat dari kontribusi faktor kerentanan sosialnya.

Bila dilihat secara lebih detil, berdasarkan analisis risiko gempabumi yang telah dibuat, wilayah Kabupaten Serang memiliki daerah berisiko tinggi seluas 42.142 ha, berisiko sedang 80.963 ha dan yang berisiko rendah seluas 22.520 ha. Kecamatan yang memiliki luasan daerah berisiko tinggi terbesar adalah Kecamatan Cinangka yaitu seluas 11.201 ha, sedangkan kecamatan yang tidak mempunyai wilayah risiko tinggi ada 2, yaitu Kecamatan Gunungsari dan Kecamatan Pontang. Bila diambil 5 urutan kecamatan yang mempunyai area berisiko tinggi, secara berturutan adalah Kecamatan Cinangka, Padarincang (6.207 ha), Ciomas (2.954 ha), Petir (2.822 ha) dan yang ke 5 adalah Kecamatan Kramatwatu (2.213 ha).

Berdasarkan tingkatan wilayah desa, desa yang mempunyai luas wilayah berisiko tinggi terluas adalah Desa Bantarwaru, Kecamatan Cinangka (1.417 ha), Desa Kubang Baros, Kecamatan Cinangka (1.373 ha), Desa Cikolelet, Kecamatan Cinangka (1.176 ha), Desa Umbultanjung, Kecamatan Cinangka (1.143 ha), dan Desa Cibojong, Kecamatan Padarincang 
(1.074 ha). Ternyata sebagian besar dari kelurahan yang berisiko tinggi ada di bagian

barat daya yang termasuk ke dalam zona bahaya tingkat tinggi.

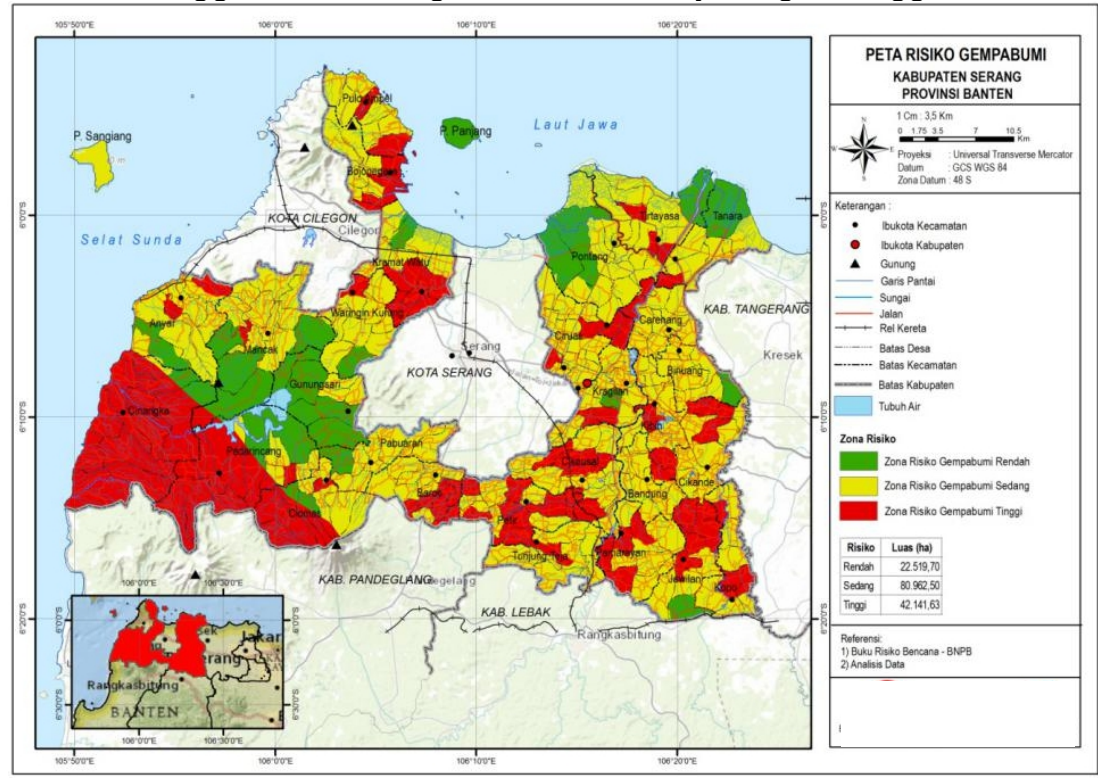

Gambar 6. Peta Risiko Bencana Gempabumi di Kabupaten Serang (Sumber: Hasil Pengolahan Data, 2017)

\subsection{Rencana Tindak dalam Pencegahan, Mitigasi, dan Kesiapsiagaan Bencana Gempabumi di Kabupaten Serang}

Data dan informasi mengenai peta bahaya, peta kerentanan dan peta risiko bencana gempabumi di Kabupaten Serang bisa untuk menjadi acuan dalam upaya pengurangan risiko bencana. Berikut adalah beberapa rencana tindak untuk pengurangan risiko bencana gempabumi dalam setiap tahapan kondisi (pencegahan, adaptasi, mitigasi, dan kesiapsiagaan) yang bisa dilakukan oleh Pemerintah Kabupaten Serang.

\subsubsection{Pencegahan, Adaptasi, dan Mitigasi Bencana}

Kaitannya dengan pencegahan, adaptasi, dan mitigasi bencana, Pemerintah Kabupaten Serang perlu melakukan beberapa kegiatan yang antara lain adalah:

a. Pengenalan dan pemantauan risiko bencana gempabumi,

b. Penerapan upaya mitigasi struktural dan nonstruktural bencana gempabumi,

c. Penetapan tata ruang dan tata guna lahan berbasis risiko bencana gempabumi,

d. Pengaturan pembangunan dan tata bangunan (building code) berbasis risiko bencana gempabumi, e. Pengelolaan lingkungan hidup yang berwawasan risiko bencana gempabumi,

f. Peningkatan aksesibilitas bangunan strategis dan penting di daerah rawan agar memenuhi standar kedaruratan bencana gempabumi,

g. Menyusun standarisasi keandalan bangunan gedung yang dapat dijadikan dasar bagi perizinan bangunan gedung (IMB).

\subsubsection{Kesiapsiagaan}

Pemerintah Kabupaten Serang perlu melakukan beberapa kegiatan kesiapsiagaan yang antara lain adalah:

a. Melakukan analisis hasil pengamatan gejala bencana gempabumi,

b. Pengambilan keputusan status ancaman bencana gempabumi,

c. Penyebarluasan informasi tentang peringatan bencana gempabumi,

d. Pelaksanaan tindakan terhadap ancaman bencana gempabumi,

e. Penyusunan mekanisme kesiapsiagaan dan penanggulangan bencana gempabumi,

f. Penyusunan dan uji coba rencana penanggulangan kedaruratan gempabumi,

g. Penyuluhan, pelatihan, dan gladi mekanisme tanggap darurat gempabumi,

h. Pemasangan, sosialisasi, dan pengujian sistem peringatan dini gempabumi, 
i. Penyiapan lokasi evakuasi dan jalur-jalur evakuasi,

j. Sosialisasi bencana gempabumi (BPPTBPBD Kabupaten Serang, 2017).

\section{KESIMPULAN}

Kabupaten Serang yang merupakan bagian dari kawasan Selat Sunda. Kawasan tersebut terletak di antara dua lempeng dunia, yaitu Lempeng Indo-Australia dan Lempeng Eurasia yang menghasilkan salah satu aktivitas tektonik dan kegempaan yang sangat tinggi.

Hasil analisis bahaya gempabumi, zona bahaya gempabumi tinggi di Kabupaten Serang terdapat di bagian barat daya, yaitu di sebagian kecamatan-kecamatan Cinangka, Padarincang, Ciomas, Mancak, dan Anyar. Analisis kerentanan dengan menggunakan kerentanan sosial, sebagai parameter adalah kepadatan penduduk, rasio jenis kelamin, rasio kemiskinan, rasio orang cacat, dan rasio kelompok umur. Analisis risiko bencana gempabumi melibatkan parameter bahaya dan kerentanan, diklasifikasikan menjadi 3 kelas, yaitu tingkat risiko rendah, sedang, dan tinggi.

Kecamatan yang mempunyai luas risiko tertinggi adalah Kecamatan Cinangka. Berdasarkan tingkatan wilayah desa, desa yang mempunyai luas wilayah berisiko tinggi terluas adalah Desa Bantarwaru, Kecamatan Cinangka (1.417 ha), Desa Kubang Baros, Kecamatan Cinangka (1.373 ha), Desa Cikolelet, Kecamatan Cinangka (1.176 ha), Desa Umbultanjung, Kecamatan Cinangka (1.143 ha), serta Desa Cibojong, Kecamatan Padarincang (1.074 ha).

Analisis risiko bencana gempabumi di Kabupaten Serang sangat diperlukan dalam menyediakan data dan informasi kebencanaan. Data dan informasi tersebut menjadi acuan untuk rencana tindak dalam pengurangan risiko bencana gempabumi dalam setiap tahapan kondisi (pencegahan, adaptasi, mitigasi, dan kesiapsiagaan), serta proses perencanaan pembangunan yang lebih efektif dan terintegrasi untuk mengurangi dampak korban jiwa maupun harta yang mungkin terjadi.

\section{DAFTAR PUSTAKA}

BNPB. 2012. Peraturan Kepala Badan Nasional Penanggulangan Bencana Nomor 02 Tahun 2012 Tentang Pedoman Umum Pengkajian Risiko Bencana.
BNPB. 2016. Buku Risiko Bencana Indonesia.

BPPT-BPBD Kabupaten Serang. 2017. Master Plan dan Action Plan Kebencanaan Kabupaten Serang, Laporan, tidak diterbitkan.

BPS Kabupaten Serang. 2018. Kabupaten Serang Dalam Angka 2018.

Candra, A.D., B.J. Santosa, and G. Rachman. 2017. Seismic Anisotropy Analysis Beneath Sumatra Revealed by Shear-Wave Splitting. Indonesian Journal on Geoscience, 4 (3), p.169-179. DOI: 10.17014/ijog.4.3.169-179;

Handayani, L. dan H. Harjono. 2008. Perkembangan Tektonik Daerah Busur Muka Selat Sunda dan Hubungannya dengan Zona Sesar Sumatra. Jurnal Riset Geologi dan Pertambangan 18(2): 31-40.

Harjono, H., M. Diament, J. Dubois, M. Larue, M.T. Zen. 1991. Seismicity of the Sunda Strait: Evidence for Crustal Extension and Volcanological Implication, Tectonics 10 (1):1730.

Kementerian Pekerjaan Umum. 2017. Peta Sumber dan Bahaya Gempa Indonesia Tahun 2017.

Naryanto, H.S. 2003. Mitigasi Kawasan Pantai Selatan Kota Bandar Lampung, Propinsi Lampung Terhadap Bencana Tsunami. Jurnal Alami. 8(2): 28-32.

Naryanto, H.S. 2008. Analisis Potensi Kegempaan dan Tsunami di Kawasan Pantai Barat Lampung Kaitannya dengan Mitigasi dan Penataan Kawasan, Jurnal Sains dan Teknologi Indonesia. 10(2): 71-77.

Naryanto, H.S. 2017. Potensi Gempa dan Tsunami di Kabupaten Banggai Laut, Provinsi Sulawesi Tengah. Jurnal Sains dan Teknologi Mitigasi Bencana. 12(2): 46-60.

Naryanto, H.S. 2019a. Analisis Bahaya Kerentanan dan Risiko Bencana Tsunami di Provinsi Papua Barat. Jurnal Alami 3(1): 1020.

Naryanto, H.S. 2019b. Kajian Bahaya Tsunami di Pantai Utara Kabupaten Serang, Jurnal Alami. 3(2): 112-121

Naryanto, H.S \& Q. Zahro. 2017. Pembuatan Peta Bahaya, Kerentanan dan Risiko Bencana Gempabumi Kabupaten Serang. Laporan, tidak dipublikasikan.

Pemerintah Kabupaten Serang. 2019. Perubahan Peraturan Daerah (Perda) Nomor 10 Tahun 2011 Tentang Rencana Tata Ruang Wilayah (RTRW) Tahun 2011-2031.

Rusmana, E., K. Suwitodirdjo, Suharsono. 1991. Peta Geologi Lembar Serang Skala 1:100.000. Pusat Penelitian dan Pengembangan Geologi, Bandung. 
Soehaimi, A. 2008. Seismotektonik dan Potensi Kegempaan Wilayah Jawa. Jurnal Geologi Indonesia, 3(4): 227-240

Soehaimi, A., Y. Sopyan, R.M. Wahyudiono dan R. Isnu Sulistyawan. 2019. Seismotektonik dan Potensi Bencana Gempabumi Selat Sunda dan Sekitarnya, dalam Moch. Wachyudi Memed, M.W., A. Soehaimi, H. Gunawan. 2019. Dinamika Geologi Selat Sunda Dalam Pembangunan Berkelanjutan.pp 135-153.

Undang-Undang Republik Indonesia Nomor 24 Tahun 2007 Tentang Penanggulangan Bencana.

USGS, NEIC. 2017. Seismic Hazard of Western Indonesia, Map Prepare by United State of Geology Survey, URL http://earthquake.usgs.gov/research/hazmap/ product_data/

Wilson, P., J. Rais, C. Reigber, E. Reinhart, Ambrosius, B. a. C., Le Pichon, X., Kasser, M., P. Suharto, D. A. Majid, D.P.A.H.O.B.H. Yaakub, R. Almeda and C. Boonphakdee. 1998. Study Provides Data on Active Plate Tectonics inSoutheast Asia Region. Transactions American Geophysical Union, 79(45), p.545-549. DOI: 10.1029/98EO00398.

Yudhicara dan K. Budiono. 2008. Tsunamigenik di Selat Sunda, Kajian Terhadap Katalog Tsunami Soloviev. Jurnal Geologi Indonesia 3(4): 241-251. 